\title{
EFFECT OF ATRIPLEX NUMMULARIA LEAVES MEAL AS A NON-TRADITIONAL FEEDSTUFF IN LOCAL GROWING HENS UNDER SOUTH SINAI CONDITIONS
}

\author{
K. Abd El-Galil; Mona M. Hassan; A.A. Abd El-Dayem; K.M. Abu El-Soud and Fayza M. \\ Salem
}

Animal and Poultry Nutrition Department, Desert Research Center, Cairo, Egypt.

(Received 1/10/2015, Accepted 20/11/2015)

\section{SUMMARY}

\begin{abstract}
A total number of 180 Sina growing hens 10 weeks of age were used in an experiment till 18 weeks of age. The experiment aimed to study effect of feeding growing hens different levels of Atriplex nummularia leaves meal (ALM) on their performance and feed cost under South Sinai conditions. Experimental birds were divided randomly into four equal experimental treatments (45 in each treatment) and randomly divided into three equal replicates (15 hens each). The first group was fed the basal diet as a control treatment $(0 \%$ ALM), while the other three treatments were fed diets containing either 4,8 or $12 \%$ ALM, respectively. Experimental diets were formulated to be iso-caloric $(2800 \mathrm{kcal} \mathrm{ME} / \mathrm{kg}$ diet) and iso-nitrogenous ( $15 \%$ crude protein), iso-fibrous $(3.15 \%)$ and were formulated in granular form. The inclusion of $8 \%$ ALM showed improve in live body weight, weight gain and feed conversion ratio with .greater net return and economical efficiency in the diet compared to the other levels. while, decrease $(\mathrm{P}<0.05)$ in live body weight, weight gain and feed intake with the inclusion of $12 \%$ ALM in the diet compared to the other levels, Increasing $12 \%$ ALM level in the diets significantly decreased $(\mathrm{P}<0.05)$ digestion coefficients of OM, CP, CF, NFE\% and nutritive values expressed as DCP, TDN \% and ME $(\mathrm{kcal} / \mathrm{kg}$ ) up to $12 \%$. However, $12 \%$ of ALM significantly increased $(\mathrm{P}<0.05)$ digestion coefficient of EE. In conclusion, from the nutritional and economical efficiency stand points of view, up to $8 \%$ ALM could be recommended to be used successfully and safely when formulating diet for Sina local growing hens without adversely affecting their performance.
\end{abstract}

Keywords: local growing hens, performance, Atriplex nummularia leaves meal, digestibility and economical efficiency.

\section{INTRODUCTION}

Poultry sector represents an important part of the economic and food security in Egypt. Poultry is considered the main source of white meat and eggs. There is a large gap between the traditional requirements and resources of feed for poultry, there is considerable attention to use untraditional feed sources in poultry diets sush as halophytes plants. These plants tolerate high levels of salinity in the soil and widely distributed at the most arid and semiarid regions with high amount of biomass production. The suitable halophytic plant species that show better adaptability and chances of establishment are Atriplex (Le Houerou, 1991 and 1992). High salt and tanin content is the major negative component in Atriplex species (Wilson, 1992). There are over 250 species in the Atriplex genus, mostly in sub-tropical and temperate regions of the world. Atriplex nummularia, commonly called old Man Saltbush. Atriplex nummularia is widespread in semi-arid and arid regions. However, it is very adaptable and can occur on most soils (saline and clay soils). Atriplex nummularia in developing countries are used to alleviate the problem of poultry feeding and decrease poultry feed cost. Also, it is palatable and remains green even during droughts and maintain a relatively high crude protein throughout the year. Some researches added the Atriplex nummularia leaves meal (ALM) in poultry diets such as Abd El-Galil et al. (2014) who include ALM up to $8 \%$ in local Sina laying hens and found an improvement in live body weight change. Therefore, Abd El-Galil and Khidr (2001) showed that weaning rabbits performance were not adversely affects with using ALM in their diet up to $25 \%$. The Atriplex nummularia leaves meal (ALM) can be used in growing hens nutrition as a substitute percentage for the conventional feedstuffs as Amin (1999) who used the dried green leaves of Atriplex nummularia in growing turkey diet. There is no available known report on the possibility of using ALM in growing hen diets. The main object of this experiment was 
estimate the effect of adding ALM in Sina local growing hens diet on their performance and feed cost under desert conditions.

\section{MATERIALS AND METHODS}

The current study was carried out at south Sinai Experimental Research Station (Ras-Suder City) which belongs to the Desert Research Center, during the period from July to August, 2013. The experiment aimed to study effect of feeding growing hens different levels of Atriplex nummularia leaves meal (ALM) on the performance and economical efficiency of feed under south Sinai conditions. A total number of 180 Sina growing hens 10 week of age were used in this study till 18 weeks of age. Birds were randomly distributed into four equal groups, each one has 45 hens which divided randomly into three replicates with 15 hens each .The first group was fed the basal diet as a control treatment (0\% ALM), while the other three treatments were fed diets containing either 4,8 or $12 \%$ ALM, respectively. The experimental diets were showed in Table (1). Nutrient compositions of the experimental diets were calculated according to NRC (1994). Experimental diets were formulated to be iso-caloric (2800 kcal ME $/ \mathrm{kg}$ diet) and iso-nitrogenous (15\% crude protein), iso-fibrous $(3.15 \%)$ and were formulated in granular form and water was available all time.

Table (1). Composition and proximate chemical analysis of the experimental diets.

\begin{tabular}{|c|c|c|c|c|}
\hline \multirow[t]{2}{*}{ Ingredients, $(\%)$} & \multicolumn{4}{|c|}{$\begin{array}{c}\text { Level of } \\
\text { Atriplex nummularia leaves meal }\end{array}$} \\
\hline & Control (0) & $4 \%$ & $8 \%$ & $12 \%$ \\
\hline Atriplex nummularia leaves meal & 0.00 & 4.00 & 8.00 & 12.00 \\
\hline Yellow corn & 66.57 & 66.00 & 64.94 & 65.10 \\
\hline Soybean meal (44\% CP) & 10.30 & 11.10 & 9.00 & 7.00 \\
\hline Corn gluten meal $(60 \% \mathrm{CP})$ & 5.70 & 4.70 & 5.40 & 5.00 \\
\hline Wheat bran & 10.30 & 7.54 & 6.14 & 4.50 \\
\hline Limestone ground & 1.40 & 1.30 & 1.20 & 1.12 \\
\hline Dicalcium phosphate & 1.80 & 1.50 & 1.40 & 1.38 \\
\hline Min. \&Vit. Premix* & 0.30 & 0.30 & 0.30 & 0.30 \\
\hline Dl - Methionine & 0.25 & 0.23 & 0.24 & 0.24 \\
\hline L-Lysine & 0.13 & 0.10 & 0.16 & 0.16 \\
\hline Salt & 0.25 & 0.23 & 0.22 & 0.20 \\
\hline Sand & 3.00 & 3.00 & 3.00 & 3.00 \\
\hline Total & 100 & 100 & 100 & 100 \\
\hline \multicolumn{5}{|l|}{ Proximate chemical analysis $\%$} \\
\hline Crude protein & 15.20 & 15.22 & 15.18 & 15.01 \\
\hline Crude fiber & 3.32 & 3.25 & 3.21 & 3.12 \\
\hline Ether extract & 3.30 & 3.32 & 3.25 & 3.05 \\
\hline Ash & 2.33 & 2.89 & 3.37 & 3.91 \\
\hline \multicolumn{5}{|l|}{ Calculated values: } \\
\hline Metabolizable energy $(\mathrm{kcal} / \mathrm{kg}) * *$ & 2801 & 2802 & 2803 & 2803 \\
\hline Calcium (\%) & 0.91 & 0.92 & 0.90 & 0.91 \\
\hline Available phosphorus (\%) & 0.40 & 0.41 & 0.41 & 0.41 \\
\hline Dl- Methionine $(\%)$ & 0.30 & 0.31 & 0.30 & 0.30 \\
\hline L-Lysine (\%) & 0.70 & 0.70 & 0.71 & 0.71 \\
\hline Methionine+ Cyc. (\%) & 0.55 & 0.54 & 0.55 & 0.55 \\
\hline Price $/ \mathrm{kg}$ diet (L.E.) $* * *$ & 2690 & 2610 & 2510 & 2408 \\
\hline \multicolumn{5}{|c|}{ 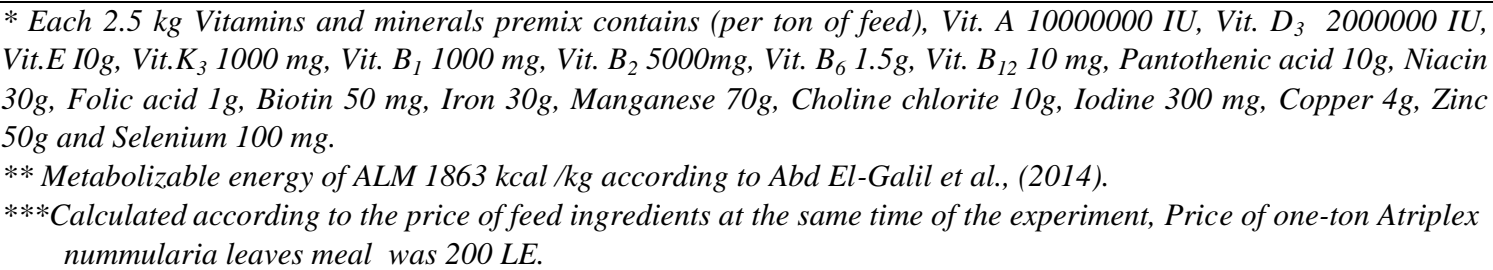 } \\
\hline
\end{tabular}


All birds were housed in wire cages of triple deck batteries. Also, the birds were exposed to daily light. The experimental birds were reared under indoor ambient temperature $(36.21 \mathrm{C} \pm 0.99)$ and relative humidity $(23.4 \mathrm{RH}(\%) \pm 1.41)$ that recorded by using the electronic digital thermo-hygrometer. Chemical analysis of ALM and the experimental diets were according to the methods of A.O.A.C. (1990). Proximate chemical analysis of ALM indicate that crude protein (CP) content was $20.13 \%$, while crude fiber (CF), ether extract (EE), nitrogen free extract (NFE) and ash were 4.01, 3.29, 41.53and $18.39 \%$, respectively. Live body weights, weight gain, feed intake and feed conversion ratio (feed/gain) were recorded monthly during the experimental period.

At the end of the experimental feeding period, digestion trials were conducted using 16 cockerels adult (4 for each level of ALM) to determine the digestion coefficients and the nutritive values (DCP and TDN) of the experimental diets as affected by ALM levels. Cockerels were housed individually in metabolic cages. The digestibility trials extended for 9 days of them 5 days as a preliminary period followed by 4 days as collection period. The individual LBW were recorded during the collection period to determine any loss or gain in the live body weights. During the main period, excreta were collected daily and weighed dried at $60{ }^{\circ} \mathrm{C}$ bulked, finally ground and stored for chemical analysis. The faecal nitrogen was determined according to Jakobsen et al. (1960). Urinary organic matter was calculated according to Abou-Raya and Galal (1971).

Apparent digestion coefficients \% of dry matter (DM), organic matter (OM), crude protein (CP), crude fiber (CF), ether extract (EE) and nitrogen free extract (NFE) of the experimental diets were estimated. The nutritive values expressed as digestible crude protein (DCP), total digestible nutrients (TDN) were calculated. Metabolizable energy (ME) was calculated as $4.2 \mathrm{kcal}$ per gram TDN as suggested by Titus (1961). The economical efficiency of feed was calculated from the input/output analysis according to the costs of the experimental diets and selling price of one $\mathrm{kg}$ birds weight. The values of economical efficiency were calculated as the net revenue per unit of total costs.

Statistical analysis of the experimental data was achieved by using General Linear Model (GLM) procedures by SAS program (2004) using simple one-way analysis of variance according to this model:

$$
\mathrm{Yij}=\mu+\mathrm{Ti}+\mathrm{eij}
$$

Where:

Yij = Represented observation in jth ALM level.

$\mu=$ Overall mean.

$\mathrm{Ti}=$ Effect of $\mathrm{jth}$ ALM level $(\mathrm{j}=0,4,8$ and $12 \%)$.

eij $=$ Random error.

Duncan's New Multiple Range Test (Duncan, 1955) was conducted to separate differences among treatment means.

\section{RESULTS AND DISCUSSIONS}

\section{Live body weight and body weight gain:}

The effect of feeding different levels of ALM on performance of Sina growing hens is summarized in Table (2). The final live body weight showed a significant differences $(\mathrm{P}<0.05)$ among experimental treatments at 10 or 14 weeks of age, It is worth noting that live body weight gain was improved ( $>>0.05)$ with increasing the ALM level in the diet up to $8 \%$.

However, the inclusion of $12 \%$ ALM in the diet was negatively affected $(\mathrm{P}<0.05)$ on the body weight at 18 weeks of age. The same trend was observed with the weight gain. Body weight gain of birds hens fed 4 or $8 \%$ ALM was higher than that of the control treatment with $2.23 \%$ or $4.29 \%$, respectively, which, while $12 \%$ ALM showed $11.75 \%$ lower than that of the control treatment. These results are in agreement with those reported by Abd El-Galil et al., (2014) who found that live body weight changes in Sina laying hens were improved with the inclusion of the ALM in the diet up to $8 \%$, while it decreased with $12 \%$ ALM. 
Table (2). Effect of feeding different levels of ALM on performance ( $\bar{X} \pm S E$ ) of Sina growing hens.

\begin{tabular}{|c|c|c|c|c|c|}
\hline \multirow{2}{*}{$\begin{array}{l}\text { Periods } \\
\text { (Weeks) }\end{array}$} & \multicolumn{4}{|c|}{ Level of ALM } & \multirow{2}{*}{ Sig. } \\
\hline & Control & $4 \%$ & $8 \%$ & $12 \%$ & \\
\hline \multicolumn{6}{|c|}{ Live body weight (LBW) (g) } \\
\hline $10 \mathrm{wk}$ & $769.65 \pm 10.43$ & $766.15 \pm 11.18$ & $750.83 \pm 9.25$ & $750.75 \pm 8.51$ & ns \\
\hline $14 \mathrm{wk}$ & $950.90^{\mathrm{a}} \pm 12.80$ & $964.65^{\mathrm{a}} \pm 13.07$ & $954.40^{\mathrm{a}} \pm 13.50$ & $891.45^{\mathrm{b}} \pm 16.00$ & $*$ \\
\hline 18 wk & $1160.40^{\mathrm{a}} \pm 18.01$ & $1165.60^{\mathrm{a}} \pm 21.03$ & $1160.80^{\mathrm{a}} \pm 23.41$ & $1095.60^{\mathrm{b}} \pm 25.02$ & $*$ \\
\hline \multicolumn{6}{|c|}{ Weight gain $(\mathrm{WG})(\mathrm{g}) / \mathrm{bird} /$ period } \\
\hline $10-14 w k$ & $181.25^{\mathrm{a}} \pm 9.13$ & $198.50^{\mathrm{a}} \pm 7.55$ & $203.57^{\mathrm{a}} \pm 8.79$ & $140.70^{\mathrm{b}} \pm 8.38$ & $*$ \\
\hline $14-18$ wk & $209.50^{\mathrm{a}} \pm 10.16$ & $200.95^{\mathrm{b}} \pm 12.40$ & $206.40^{\mathrm{ab}} \pm 17.35$ & $204.15^{\mathrm{a} b} \pm 19.17$ & $*$ \\
\hline 10- 18 wk & $390.75^{\mathrm{a}} \pm 22.63$ & $399.45^{\mathrm{a}} \pm 24.68$ & $409.97^{\mathrm{ab}} \pm 21.83$ & $344.85^{\mathrm{b}} \pm 25.11$ & $*$ \\
\hline \multicolumn{6}{|c|}{ Feed intake $(\mathrm{FI})(\mathrm{g}) / \mathrm{bird} /$ period } \\
\hline $10-14 w k$ & $730.95^{\mathrm{a}} \pm 2.86$ & $715.03^{\mathrm{a}} \pm 3.19$ & $640.67^{\mathrm{ab}} \pm 2.66$ & $595.26^{\mathrm{b}} \pm 2.52$ & $*$ \\
\hline $14-18$ wk & $867.22 \pm 2.62$ & $870.77 \pm 3.11$ & $860.06 \pm 3.52$ & $856.56 \pm 4.02$ & ns \\
\hline $10-18 \mathrm{wk}$ & $1598.17^{\mathrm{a}} \pm 2.25$ & $1585.80^{\mathrm{a}} \pm 2.18$ & $1500.73^{\mathrm{b}} \pm 2.19$ & $1451.82^{\mathrm{b}} \pm 2.92$ & $*$ \\
\hline \multicolumn{6}{|c|}{ Feed conversion ratio } \\
\hline $10-14 w k$ & $4.03^{\mathrm{ab}} \pm 0.03$ & $3.60^{\mathrm{ab}} \pm 0.01$ & $3.15^{\mathrm{b}} \pm 0.06$ & $4.23^{\mathrm{a}} \pm 0.12$ & $*$ \\
\hline $14-18 w k$ & $4.14^{\mathrm{b}} \pm 0.14$ & $4.33^{\mathrm{a}} \pm 0.14$ & $4.17^{\mathrm{ab}} \pm 0.14$ & $4.20^{\mathrm{a}} \pm 0.15$ & $*$ \\
\hline $10-18 \mathrm{wk}$ & $4.09^{a} \pm 0.16$ & $3.97^{\mathrm{ab}} \pm 0.12$ & $3.66^{\mathrm{b}} \pm 0.15$ & $4.21^{\mathrm{a}} \pm 0.19$ & $*$ \\
\hline
\end{tabular}

The reduction in live body weight apparently related to a non significant decline in feed intake also may be due to the presence of tannins, which decrease palatability and depressing body weight gain. Abd El-Galil et al., (2014) who found that the total tannins $4.2 \mathrm{mg} / 100 \mathrm{~g}$ DM in Atriplex nummularia leaves meal. In this connection, Baelum and Peterson (1964) found that the added tannin had a pronounced depressing effect on the body weight gain of the chicks by about $6 \%$.

\section{Feed intake and feed conversion ratio:}

Feed intake was significantly decreased $(\mathrm{P}<0.05)$ with increasing the level of ALM in the diet at 10 14 and 10-18 weeks of age, while this effect was not a significant at $14-18$ weeks of age. The reduction in feed intake may be due to low palatability that resulted from the astringency of tannins in Atriplex nummularia which means the sensation caused by the formation of complexes between tannins and salivary glycoproteins to cause dryness in the mouth (Swain et al., 1979, Pan et al., 1980 and Butler, 1989). In addition, Reed et al., (1990) observed that tannins may reduce cell wall digestibility by forming indigestible complexes with cell wall carbohydrate. This reduction in feed intake with the inclusion of ALM in the diet made a significant $(\mathrm{P}<0.05)$ improve in feed conversion ratio ( $\mathrm{g}$ feed/ $\mathrm{g}$ gain) with $8 \%$ ALM that was not noticed with 4 or $12 \%$ ALM inclusion in the diet. This may be attributed to the significant decrease in weight gain for those fed diet containing $12 \%$ in comparison with 8\% ALM.

\section{Digestibility and nutritive values:}

Apparent digestion coefficients \% of nutrients and nutritive values expressed as DCP, TDN \% and ME (kcal/kg) of the experimental diets as affected by the different levels of ALM are illustrated in Table (3). Results indicate a significant $(\mathrm{P}<0.05)$ decrease in digestibility coefficients \% of $\mathrm{OM}, \mathrm{CP}, \mathrm{CF}, \mathrm{NFE}$ and nutritive values by $12 \%$ ALM level in the experimental diets. On the other hand, a significant increase $(\mathrm{P}<0.05)$ was observed in digestibility coefficients of EE as affected by $12 \%$ ALM addition. It is of great importance to note that the results of the digestion trial were coincided generally with the negative response in performance of birds fed ALM.

The reduction in digestibility and nutritive values of the experimental diets may be attributed to the decrease which was observed in T3 (Triiodothyronine) hormone with increasing percentage of ALM in the diets (Abd El-Galil et al., 2014). The decrease in nutrients digestibility may also caused by the presence of tannins, which may adversely affect the nutrition of herbivores through inhibition of digestion as suggested by Reed et al. (1990) and Abd El- Galil et al. (2014) who reported that tannins may reduce cell wall digestibility by forming indigestible complexes with cell wall carbohydrate. Such tannins are naturally occurring as polyphenolic compounds and form complexes with macromolecules (proteins, cellulose, hemicellulose, starch), minerals and vitamins, which affect their availability (Makkar, 1993). 
Also, tannins may reduce the amino acid (Armstrong et al., 1974) and metabolizable energy of diet (Gous et al., 1982). Streeter et al. (1993), who found that tannins may reduce digestibility of protein and carbohydrate by inhibiting digestive enzymes and by altering permeability of the gut wall. It is of great importance to note that results of the digestion trial were coincided generally with the differences in performance and feed utilization in birds.

Table (3). Digestion coefficients $(\%)(\bar{X} \pm$ SE) of the experimental diets as affected by ALM level in growing hens diets.

\begin{tabular}{|c|c|c|c|c|c|}
\hline \multirow{2}{*}{ Item } & \multicolumn{4}{|c|}{ Level of ALM } & \multirow{2}{*}{ Sig. } \\
\hline & Control & $4 \%$ & $8 \%$ & $12 \%$ & \\
\hline $\mathrm{OM}$ & $80.64^{\mathrm{a}} \pm 1.90$ & $79.45^{\mathrm{a}} \pm 1.07$ & $76.40^{\mathrm{ab}} \pm 1.18$ & $74.17^{b} \pm 1.16$ & $*$ \\
\hline $\mathrm{CP}$ & $81.48^{\mathrm{a}} \pm 0.96$ & $80.38^{a} \pm 0.88$ & $78.44^{\mathrm{ab}} \pm 0.95$ & $75.11^{\mathrm{b}} \pm 1.01$ & $*$ \\
\hline $\mathrm{CF}$ & $24.02^{\mathrm{a}} \pm 1.91$ & $22.70^{\mathrm{a}} \pm 1.16$ & $20.40^{\mathrm{ab}} \pm 1.00$ & $17.91^{\mathrm{b}} \pm 1.83$ & * \\
\hline $\mathrm{EE}$ & $80.46^{\mathrm{b}} \pm 1.78$ & $80.95^{b} \pm 1.80$ & $84.01^{\mathrm{ab}} \pm 1.16$ & $86.88^{\mathrm{a}} \pm 1.19$ & $*$ \\
\hline NFE & $85.29^{\mathrm{a}} \pm 1.22$ & $82.34^{\mathrm{a}} \pm 1.66$ & $79.59^{\mathrm{ab}} \pm 1.28$ & $76.03^{b} \pm 1.36$ & \\
\hline DCP & $12.38^{\mathrm{a}} \pm 1.02$ & $12.23^{\mathrm{a}} \pm 1.00$ & $11.91^{\mathrm{ab}} \pm 1.03$ & $11.27^{\mathrm{b}} \pm 1.05$ & $*$ \\
\hline TDN & $61.70^{\mathrm{a}} \pm 1.78$ & $60.93^{\mathrm{a}} \pm 2.80$ & $59.35^{\mathrm{ab}} \pm 2.76$ & $56.84^{\mathrm{b}} \pm 3.72$ & * \\
\hline $\mathrm{ME}(\mathrm{Kcal} / \mathrm{kg})$ & $2591.4^{\mathrm{a}} \pm 12 . .60$ & $2559.06^{\mathrm{a}} \pm 10.61$ & $2492.0^{\mathrm{ab}} \pm 13.69$ & $23878^{\mathrm{b}} \pm 17.67$ & $*$ \\
\hline
\end{tabular}

$a, b$ : Means within the same row showing different letters are significantly different. Sig. =Significant, $*=(P<0.05)$,

ns=not significant .

\section{The economical efficiency of the experimental diets:}

Data of the economical efficiency of the study are illustrated in Table (4). The results indicated that the inclusion of $12 \%$ ALM in the diet recorded the lowest feed price that was due to the low price of ALM. On the other hand, the level of $8 \%$ ALM recorded the best net return and the percentage of economical efficiency of feed and relative economical efficiency compared to the other levels of ALM. This improvement related to the lowest feed conversion ratio of this group, as well as the constant market price of kg meat. These results are in agreement with those findings of Abd El-Galil et al. (2014).

Table (4). Economical efficiency as affected by ALM of Sina growing hens

\begin{tabular}{lcccc}
\hline Item & \multicolumn{4}{c}{ Level of ALM } \\
\cline { 2 - 5 } & Control & $4 \%$ & $8 \%$ & $12 \%$ \\
\hline Feed conversion ratio & 4.09 & 3.97 & 3.66 & 4.21 \\
Cost of kg feed (LE.) & 2690 & 2610 & 2510 & 2408 \\
Feed cost of kg gain (LE.) & 11.00 & 10.36 & 9.19 & 10.14 \\
Market price of one kg meat (LE.) & 18 & 18 & 18 & 18 \\
Net return (LE.) & 7.00 & 7.64 & 8.81 & 7.86 \\
Economical efficiency of feed (\%) & 63.64 & 73.75 & 95.87 & 77.51 \\
Relative economical efficiency & 100 & 115.86 & 150.64 & 121.79 \\
\hline
\end{tabular}

\section{CONCLUSION}

In conclusion, from the nutritional and economical efficiency stand points of view, up to $8 \%$ Atriplex nummularia leaves meal could be recommended to be used successfully and safely in the formulated diet for Sina local growing hens without adversely affecting their performance. 


\section{ACKNOWLEDGEMENTS}

This research is a part of a project nominated "utilization of some agricultural by-products and desert plants as non-conventional feedstuffs in poultry diets" which is financially supported by Ministry of International Cooperation, Egypt.

\section{REFERENCES}

Abd El-Galil, K. and R.E. Khidr (2001). Utilization of Atriplex nummularia in feeding growing rabbits under the desert and newly reclaimed areas. Egypt. Poult. .Sci. J., 21: 53-71.

Abd El-Galil, K.; R.E. Khidr; S.E.M. El-Sheikh; A.A. Salama; Mahmoud Henda, A.; Hassan Mona, M.; A.A. Abd El-Dayem and Salem Fayza, M. (2014). Utilization of Atriplex leaves meal as a nontraditional feedstuff by local laying hens under desert conditions. Egypt. Poult. Sci. J., 34 (II): 363 380 .

Abou-Raya, A.K. and A.G.H. Galal (1971). Evaluation of poultry feeds in digestion trials with reference to some factors involved. U.A.R. J. Anim. Prod., 11(1): 207-221.

Amin, E. (1999). Effects of crossbreeding and feeding different levels of Atriplex meal on production characters of local and commercial varieties of turkey. M.Sc. Thesis, Fac. Agric., Alex. Univ., Alex., Egypt.

AOAC (1990). Association of Official Analytical Chemists. Official methods of analysis, 15th. Ed., Washington, USA.

Armstrong, W.D.; J.C. Rogler and W.R. Featherston (1974). In vitro studies of the protein digestibility of sorghum grain. Poult. Sci., 53: 2224-2229.

Baelum, J. and V.E. Peterson (1964). Addition of tannin to corn and soybean meal. Forsogslaboratoriets Arbog., 338-339.

Butler, L.G. (1989). Sorghum polyphenols. Pages 95-114 in: Toxicants of plant origin, vol. 4, phenolics. P. R. Cheeke, ed. CRC Press, Boca Raton FL.

Duncan, D.B. (1955). Multiple Range and Multiple F- test, Biometrics, 11:42.

Gous, R.M.; M.A.Kuyper and C. Dennison (1982). The relationship between tannic acid content and metabolizable energy concentration of some sorghum cultivars. S. Afr. J. Anim. Sci., 12: 39.

Jakobsen, P.E.; S.G. Kirsten and H. Niclsen (1960). Fredjelighed frogmed fierbrae'Digestibility trials with poultry".Bereting fra for sogslabortoriat, Kabenhaven, 56: 1-34.

Le Houerou, H.N. (1991). The role of saltbushes (Atriplex spp.) in the developmentand rehabilitation of arid and semi-arid zones in the Mediterranean Basin. Int. Conf. on the Agricultural Management in Salt Affected Areas. Agadir. Morocco, April 26-3 May.

Le Houerou, H.N. (1992). The role of saltbushes (Atriplex spp.) in arid landrehabilitation in the Mediterranean Basin: A review, Agro forestry systems, 18: 108-148.

Makkar, H.P.S. (1993). Antinutintional factors in foods for livestock. Animal Production in Developing.Countries.Br. Soc. Anim. Prod., 16: 69-85.

NRC (1994). National Research Council. Nutrient Requirements of Poultry. 9th rev. National Academy Press, Washington, D.C., USA.

Pan, H.P.; R.W. Bullard and I. Okono (1980). "Bitter" taste in sorghum. Sorghum Newsletter, 23: 116.

Reed, J.D.; H. Soller and A. Woodward (1990). Fodder tree and straw diets for sheep: intake, growth, digestibility and the effects of phenolics on nitrogen utilization. Anim. Feed Sci. Tech., 30: 39-50.

SAS (2004). Statistical Analysis System, User's Guide, Statistics, SAS Institute, Cary, North Carolina, USA. 
Streeter, M.N.; G.M. Hill; D.G. Wagner; F.N. Owens and C.A. Hibberd (1993). Effect of bird resistant and non bird resistant sorghum gain on amino acid digestion by beef heifers. J. Anim. Sci., 71: 16481656.

Swain, T.; J.B. Harborne and C.F. van Sumere (1979). Biochemistry of plant phenolics Plenum Press, New York, NY.

Titus, H.W. (1961). The Scientific Feeding of Chickens. Danville, Illinois, USA.

Wilson, A.D. (1992). Halophytic plants communities in Australia: Ecology and potential as a rangeland resource. Proc. Inter. Workshop. Halophytes as a resource for livestock and for rehabilitation of degraded land.

Wilson, A.D. (1992). Halophytic plants communities in Australia: Ecology and potential as a rangeland resource. Proc. Inter. Workshop. Halophytes as a resource for livestock and for rehabilitation of degraded land.

\title{
تاثير مسحوق اوراق القطف كمادة علف غير تقليدية فى علائق الدجاج النامى تحت ظروف جنوب سيناء.
}

\author{
خالد عبد الجليل، منى محمد على، عبد الدايم عبد العزيز، كمال مرسى ابو السعود و فايزة محمد منصور سالم \\ قسم تغذية الحيوان و الدواجن، مركز بحوث الصحراء، القاهرة، مصر.
}

استخدم في هذا البحث عدد 180 دجاجه سينا نامى عمر 10 اسبوع حتى عمر 18 اسبوع ع ـ حيث هدفت التجربة إلى دراسة تأثير

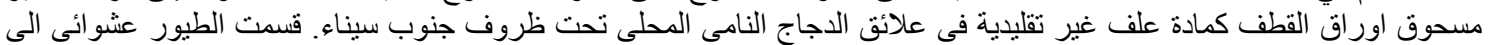

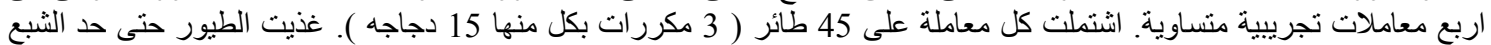

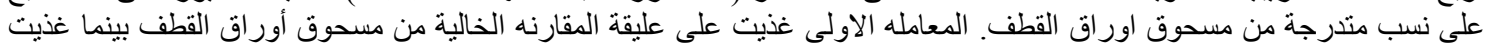

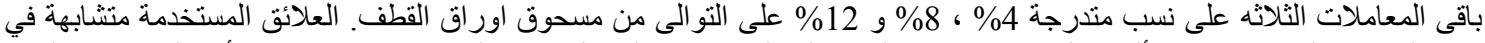
نسبة البروتين الخام 15\% ، الألياف الخام 3.15 \% و الطاقة الممثلة \% \% 2800 كيلو كالورى /كيلوجر ام ـ ويمكن إيجاز أهم النتائج فى النقاط

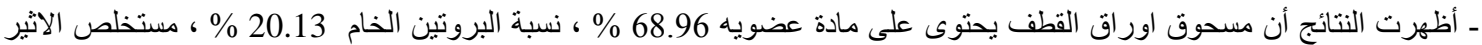

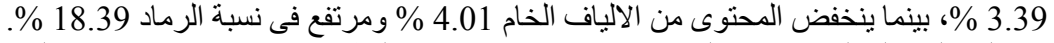

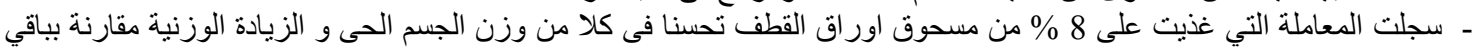

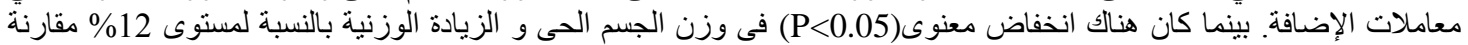
بالمستويات الاخرى.

ـ لوحظ انخفاض معدل استهلاك الغذاء خلال فترة التجربة وذللك بزيادة نسبة إضافة مسحوق اوراق القطف في العليقه. وقد سجلت

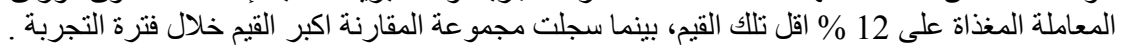

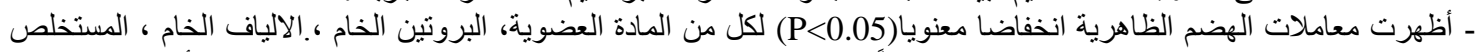

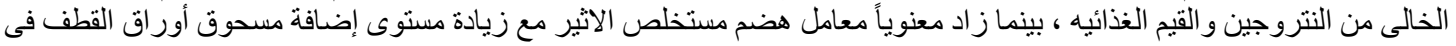
العليقة. ـ تحقق أفضل عائد صافي للتغذية بالإضافة إلى افضل كفاءة اقتصادية عند مستوى 8 \% خلال فترة التجربة مقارنة بباقي مستويات الإضـافة في العليقة .

يمكن التوصية من الوجهة الغذائية والاقتصادية إمكانية استخدام مسحوق اوراق القطف في علائق الدجاج المحلى النامى حتى مستوى الإنى 8 \% دون تأثير سلبي على معدلات أداء النمو و العائد الاقتصادي. 